"The relationship between organizational citizenship behavior and organizational performance (case study: Agricultural Jihad Organization of Mazandaran Province)"

$\begin{array}{ll} & \text { Ghasem Sadeghi } \\ \text { AUTHORS } & \text { Masoud Ahmadi } \\ & \text { Maryam Taghvaee Yazdi }\end{array}$

Ghasem Sadeghi, Masoud Ahmadi and Maryam Taghvaee Yazdi (2016). The

ARTICLE INFO relationship between organizational citizenship behavior and organizational performance (case study: Agricultural Jihad Organization of Mazandaran Province). Problems and Perspectives in Management, 14(3-si), 317-324. doi:10.21511/ppm.14(3-si).2016.03

DOI http://dx.doi.org/10.21511/ppm.14(3-si).2016.03

RELEASED ON Thursday, 15 September 2016

JOURNAL

"Problems and Perspectives in Management"

FOUNDER

LLC "Consulting Publishing Company "Business Perspectives"

NUMBER OF REFERENCES

0
NUMBER OF FIGURES

0

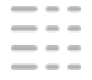

NUMBER OF TABLES

0

(C) The author(s) 2023. This publication is an open access article. 


\title{
The relationship between organizational citizenship behavior and organizational performance (case study: Agricultural Jihad Organization of Mazandaran Province)
}

\begin{abstract}
The main purpose of this study is analyzing the relationship between organizational citizenship behavior and market orientation. This study is an applied research in terms of the purpose based on a descriptive correlational method. The statistical population included all employees of Agricultural Jihad Organization of Mazandaran province consisting of 1923 persons. 391 people (male and female) were selected using random stratified sample. Data were collected through two standard questionnaires: Podsakoff's (2003) organizational citizenship behavior (24 questions) and Fazel's (2012) organizational performance (13 questions). Validity of questionnaires was confirmed by experts and reliability of them was confirmed using Cronbach's coefficient alphabet. Cronbach's alpha for the organizational citizenship behavior and organizational performance was calculated by 0.80 and 0.87 . Components of organizational citizenship behavior included civic virtue, altruism, conscientiousness, sportsmanship, and courtesy. Components of organizational performance included customer satisfaction, employee satisfaction, organizational effectiveness, and financial results and the market. Data were analyzed using descriptive and inferential statistics through SPSS software. The descriptive statistics included frequency, percentage, mean, and standard deviation and inferential statistics included KolmogorovSmirnov, Spearman's rank correlation coefficient, Fisher's z-distribution using SPSS software.
\end{abstract}

Keywords: organizational citizenship behavior, employees, organizational performance, Agricultural Jihad, Mazandaran Province.

JEL Classification: D23, M12, M10.

\section{Introduction}

In today's world, knowledge is a key source. The creation of collective knowledge for organizational success is a strategic task (Brief \& Motowidlo, 1986). Organizations are not able to develop the effectiveness of their collective wisdom without voluntary willingness of individuals to cooperate and the difference voluntary and compulsory collaboration are important. According to compulsory collaboration, individuals do their duties in accordance with law, regulation and standard acceptable to the organization. According to voluntary cooperation, individuals do the duties beyond their responsibilities and use their energy and insight for developing their abilities in favor of organization. Thus, individuals often ignore their personal interests and their responsibility is in favor of the others' interests (Vigoda, 2000). Organizational citizenship behavior (OCB) is an extra-role behavior by which employees improve organizational performance. Several studies have been carried out about the relationship between organizational citizenship behavior and organizational performance. Today, the emphasis of managers is on creating conditions for organizational obedience, organizational

(C) Ghasem Sadeghi, Masoud Ahmadi, Maryam Taghvaee Yazdi, 2016. Ghasem Sadeghi, Master of Business Administration, Department of Business Management, Sari Branch, Islamic Azad University, Sari, Iran. Masoud Ahmadi, Assistant Professor, Department of Management, Sari Branch, Islamic Azad University, Sari, Iran.

Maryam Taghvaee Yazdi, Assistant Professor, Department of Educational Management, Sari Branch, Islamic Azad University, Sari, Iran. loyalty, and organizational participation as the concept of organizational citizenship due to greater use of the endless human capacity to increase the quantity and quality of products and services in a world of competition and change (Ahmad, 2013, p. 49). Studies generally argue that Organizational citizenship behavior for the organization is positive and has many benefits both for managers and employees. Managers who believe in OCB provide a desirable environment for cooperation of the members of the organization. OCB helps managers to spend less time on how to direct employees to perform their duties and focus on opportunities to improve organizational performance (Turnipseed \& Rassuli, 2005).

\section{Theoretical foundations}

1.1. Organizational citizenship behavior. Organizational citizenship behavior is set of behaviors that are not part of the formal requirements of the job, but helps the effectiveness of work and organizations. Employees often consider these behaviors optional. Therefore, they cannot be officially recognized. The definition of organizational citizenship behavior represents the fact that these behaviors have a certain impact on the effectiveness of the organization through adding social framework to the workplace. There are several reasons to justify why organizational citizenship behavior affects the effectiveness of the organization: increasing management productivity, reducing the need to extend scarce resources, creating an environment that increases employee morale (Organ, 1995). 
The concept of organizational citizenship behavior was first proposed by Batman and Organ in the early 1980s. Most of initial researches on organizational citizenship behavior were to identify responsibility or behaviors of employees in the organization, but they were often ignored. Although these behaviors were partially measured for the traditional evaluation of job performance and sometimes were neglected, they were effective in improving organizational effectiveness (Bienstock et al., 2003, p. 360). The actions that occur in the workplace are defined as follows: a set of voluntary behaviors that are not part of the official duties of the individual, but improve the organizational roles (Appelbaum et al., 2004, p. 19).

Graham (1991) believes that there are three types of OCB: (1) Organizational compliance: This term describes the behaviors whose necessity and desirability are identified and they are accepted in a rational structure of discipline. Indicators of organizational compliance include behaviors such as respecting the organizational rules, performing tasks, and carrying out the responsibilities with regard to organizational resources. (2) Organizational loyalty: The loyalty to the organization is different from the loyalty to other individuals and organizational sectors and represents the dedication of employees in the organization to defend the interests of the organization. (3) Institutional partnerships: This term will emerge from its involvement in managing the organization, such as attending meetings, sharing their beliefs with others and an awareness of current issues of the organization (Appelbaum et al., 2004, p. 19).

Based on literature review, OCB can be categorized into seven types (Podsakoff et al., 2000): (1) helporiented behaviors, (2) sportsmanship, (3) individual growth, (4) organizational commitment, (5) individual innovativeness, (6) civic virtue, (7) self-satisfaction. Bolino and et al (2002) introduced six components for OCB: Loyalty, Dutifulness, Participation (social, supportive, and civic), Attention and courtesy, Sacrifice, Sportsmanship (Bolino and et al., 2002). The most valid classification of OCB dimensions might be related to Organ which has being applied in various researches. The dimensions are:

- Civic virtue reflects behaviors which indicate responsibly participation of individual in organization affairs and valuing of the organization.

- Altruism is a discretionary behavior which by considering organization relations and tasks, aims to assist others.

- Conscientiousness is a discretionary behavior to assist organization which employees normally go beyond their duties.
- Sportsmanship is employees' tendency to tolerate the condition which is the least condition for them, without complaining.

- Courtesy includes activities which help to avoid emergence of probable issues which is due to interaction with others.

Civic virtue refers to the constructive involvement in the political process of the organization and contribution to this process by freely and frankly expressing opinions, attending meetings, discussing with colleagues the issues concerning the organization, and reading organizational communications such as mails for the wellbeing of the organization. Organ defined conscientiousness as dedication to the job which exceed formal requirements such as working long hours, and volunteer to perform jobs besides duties.

Organ also believes that people with progressive citizenship behavior continue their work in the worst conditions and even in the case of sickness and disability. Altruism in simple words means helping or helpfulness. Altruism means helping other members of the organization in their tasks. For, e.g., voluntarily helping new employees, helping co-workers who are overloaded, assisting workers who were absent, and guiding employees to accomplish difficult tasks. Sportsmanship and courtesy represents avoiding the damage to the organization. Sportsmanship is defined as a willingness to tolerate the inevitable inconveniences and impositions of work without complaining. Courtesy refers to the gestures that help others to prevent interpersonal problems from occurring, such as giving prior notice of the work schedule to someone who is in need, consulting others before taking any actions that would affect them (Mostabsary and Nejabaty, 2008; Rezaee Kelid Bari and Bagher Salimi, 2008; Eslami, 2008).

1.2. Organizational performance. One of the important questions in business is that why some organizations are successful in spite of their failure in the completion with other organization. Organizational performance is the most important issue for profit and non-profit organizations. Awareness of the factors affecting the performance of the organization is very important for managers, because it is important to take appropriate steps at the beginning. However, definition, conceptualization, and measurement of performance are not easy. Researchers have different beliefs and definitions about organizational performance, but still remains a controversial issue (Barney, 1997).

Performance literally means the quality of work. So, organizational performance is an overall structure referring to the organizational operation (Rahnavard, 2008). According to the definition of Khavier (2002), 
the performance is equal to economy, efficiency and effectiveness for a specific program or activity. However, Daft (2000) states that organizational performance is an organizational activity to achieve the objectives of using resources effectively. Richard (2001) also states that organizational performance is an organizational activity to achieve the organization's goals and objectives (quoted by Abo-jarard, Yosoph, Nick Bin, 2010).

Ho L. A. (2008) states that organizational performance is an indicator measuring achieving the objectives of an organization or institution. Stoner et al. (1995) argue that organizational performance is determined by organizational efficiency and effectiveness in achieving the objectives (quoted by Alagheband, 2010). According to Neely et al. (2002), performance is defined as the process of quantifying the efficiency and effectiveness of past actions. According to this definition, the performance is divided into two components: 1) efficiency which describes how the organization uses resources in production and services, i.e., the relationship between the real and the ideal combination of inputs to produce specific outputs, and 2) effectiveness which describes the degree achieving organizational goals. These goals are usually described in the form of appropriateness (the degree of outputs in accordance with the requirements of customers), availability (aspects such as frequency, providing among the priority groups, and physical gap), and quality (the degree of fulfillment of required standards) (Dollery \& Worthington, 1996).

Organizational performance is an issue that can be considered from the perspective of different stakeholders. Thus, there are several interpretations about what could be called as successful performance (Carton, 2004). In general, performance has been studied in the field of management, including studies conducted by Dess \& Robinson (1984), Rawley \& Lipson (1985), Chakravarthy (1986), Venkatraman \& Ramanujam (1987), Brush \& Vander Werf (1992) and Murphy, Trailer and Hill (1996).

After reviewing the articles published between 1996 and 2001 in five authentic scientific research journals, including Journal of the Academy of Management, Strategic Management Journal, Journal of Management, Journal of business investment, and journal of Theory and practice in the field of entrepreneurship, Carton (2004) found that among 138 articles in which the organizational performance was considered as the dependent variable, $70 \%$ of the articles introduced profitability, $27 \%$ of the articles introduced growth, $17 \%$ of the articles introduced market-based criteria and $18 \%$ of the articles introduced measures based on operations as the dimension of the performance and other dimensions were introduced in $4 \%$ of the articles. In most of the researches, profitability and growth were considered as organizational performance variables. Fazel (2012) argues that measurement of organizational performance should be based on appropriate indicators. In this regard, the four performance variables that are taken into consideration in order to measure the performance of organizations include employee satisfaction, customer satisfaction, organizational effectiveness, and financial results and the market. Piercy (1995) and Ahmed Rafiq and Saad (2003) considered customer satisfaction and competitive market position as the factors affecting organizational performance.

\section{Literature review}

Bambale (2011) conducted a study and concluded that there is a significant relationship between organizational citizenship behavior and performance. In a study conducted by Tai \& et al (2012), they argued that the role of organizational citizenship behavior is significant and positive in increasing organizational performance. Researchers have mentioned individual and organizational outcomes for organizational citizenship behaviors. At the organizational level, enhancing the performance and effectiveness is the main issue (Winer, 2001). According to the new concepts about performance, it should be noted that this issue does not seem too farfetched and unreasonable. However, many studies have been carried out to identify how to enhance performance and organizational effectiveness through increasing organizational citizenship behaviors (Bass and Avolio, 1993). In early studies carried out in this area, researchers found that citizenship behaviors are associated with high performance (Magliocca \& Christakis, 2001). They found that employees who work in organizational units with high-performance pay attention to citizenship behaviors more than those who work in organizational units with lowperformance (Kark, 2004). In a survey of fast food restaurants, they concluded that various citizenship behaviors are at least associated with some indicators of organizational performance. After a long study (in a sample of 28 restaurants), they found that there is a significant relationship between citizenship behaviors and organizational effectiveness (George and Brief, 1992).

In a study conducted by Chen et al. (1998), they found that there is an inverse relationship between organizational citizenship behaviors and employees' interest in turnover. In other words, increasing organizational citizenship behaviors reduce the rate of employees' interest in turnover. On the other hand, decreasing the rate of employees' interest in turnover can lead to a better performance and effectiveness in the organization. Thus, one of the mechanisms of action of organizational citizenship behaviors in 
increasing the performance and effectiveness of the organization is the reduction in turnover rate (Kark, 2004). Another issue that some researchers (such as Podsakoff, 2000), consider as a result of organizational citizenship behaviors is increasing the organization's ability to attract and retain qualified and efficient forces (Winer, 2001). A high level of organizational citizenship behaviors in an organization causes it to become an attractive environment to work. Therefore, organizations having a high level of citizenship behaviors will have a better performance with effective recruitment (Schappe, 1998).

Mehrdad \& et al (2005) conducted a study entitled "the relationship between organizational citizenship behavior and job performance". The results of their study indicated that there is a significant relationship between job performance and organizational citizenship behavior. Jalil (2010) conducted a study entitled "the relationship between organizational citizenship behavior and job performance". The results of their study indicated that there is a significant relationship between job performance and organizational citizenship behavior and dimensions of organizational citizenship behavior can predict job performance. Ekhlasi (2011) conducted a study entitled "the relationship between organizational climate and organizational citizenship behavior, and job performance of employees in Shiraz University of Medical Sciences". The results of this study indicated that there is a significant relationship between job performance and organizational citizenship behavior.

\section{Theoretical framework and analytical model of research}

The theoretical model was proposed by summing up the theories and empirical research findings. The research conceptual model derived from the research literature is presented as follows:

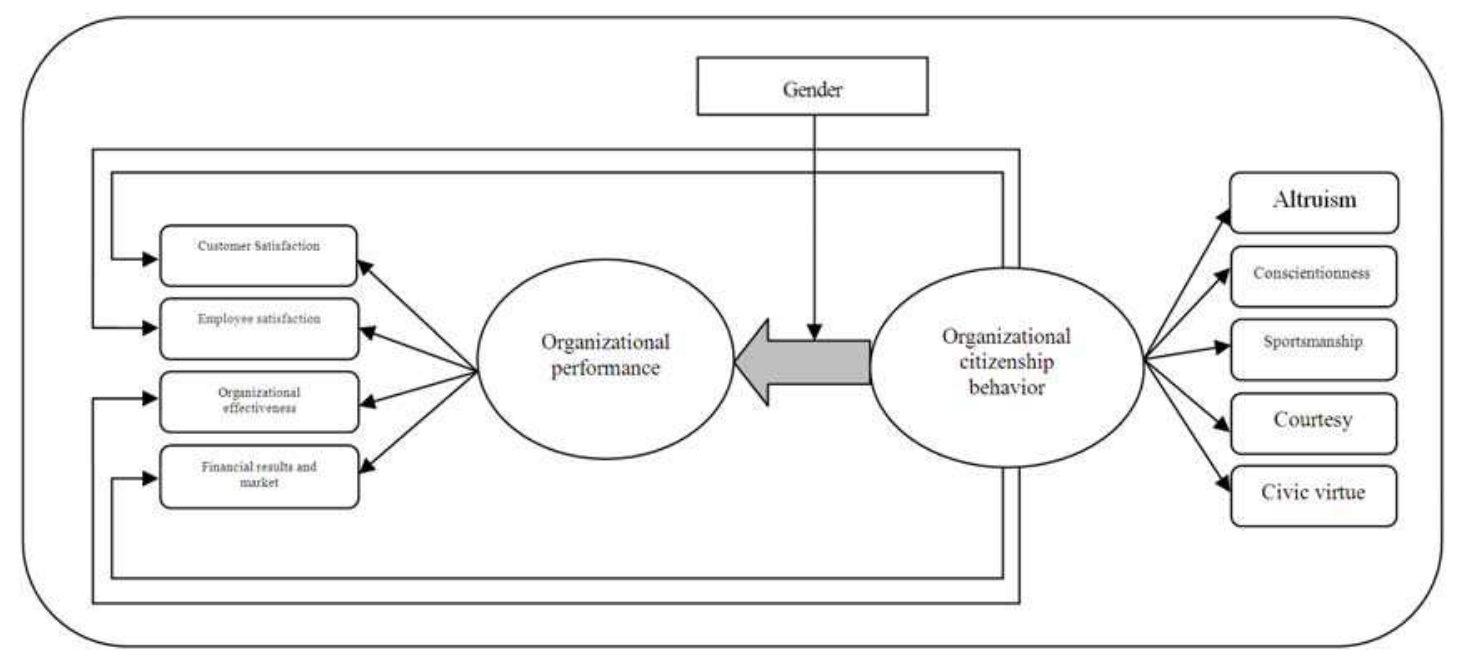

Fig. 1. Research conceptual model

This study seeks to answer the main question: "Is there a significant relationship between organizational citizenship behavior and organizational performance?" Thus, the following hypotheses were posed:

- First hypothesis (main hypothesis): there is a significant relationship between organizational citizenship behavior and organizational performance.

- Second hypothesis: there is a significant relationship between organizational citizenship behavior and customer satisfaction.

- Third hypothesis: there is a significant relationship between organizational citizenship behavior and employee satisfaction.

- Furth hypothesis: there is a significant relationship between organizational citizenship behavior and organizational effectiveness.

- Fifth hypothesis: There is a significant relationship between organizational citizenship behavior and financial results and the market.
- Sixth hypothesis: There is a difference between organizational citizenship behavior and organizational performance in terms of gender.

\section{Methodology}

This study is an applied research in terms of the purpose based on a descriptive correlational method. The statistical population included all employees of Agricultural Jihad Organization of Mazandaran province consisting of 1923 persons. 391 people (male and female) were selected using random stratified sample. Data were collected through two standard questionnaires: Podsakoff's (2003) organizational citizenship behavior (24 questions) and Fazel's (2012) organizational performance (13 questions). Validity of questionnaires was confirmed by experts and reliability of them was confirmed using Cronbach's coefficient alphabet. Cronbach's alpha for the organizational citizenship behavior and organizational performance was calculated by 0.80 and 0.87 . 
Components of organizational citizenship behavior included civic virtue, altruism, conscientiousness, sportsmanship, and courtesy. Components of organizational performance included customer satisfaction, employee satisfaction, organizational effectiveness, and financial results and the market. Data were analyzed using descriptive and inferential statistics through SPSS software. The descriptive statistics included frequency, percentage, mean, and standard deviation and inferential statistics included KolmogorovSmirnov, Spearman's rank correlation coefficient, Fisher's z-distribution using SPSS software.

\section{Findings}

Table 1. Distribution of the percentage frequency of respondents in terms of gender

\begin{tabular}{|l|c|c|}
\hline \multicolumn{1}{|c|}{ Gender } & Frequency & Percentage frequency \\
\hline Men & 260 & 66.5 \\
\hline Women & 131 & 33.5 \\
\hline Total & 391 & 100 \\
\hline
\end{tabular}

As shown in Table 1, 66.5\% of respondents were male and $33.5 \%$ of them were female.

Table 2. Results of Kolmogorov-Smirnov test to for normal distribution of data

\begin{tabular}{|l|c|c|c|}
\hline \multicolumn{1}{|c|}{ Component } & $\begin{array}{c}\text { Kolmogorov- } \\
\text { Smirnov }\end{array}$ & DF & Probability value \\
\hline Customer satisfaction & 0.089 & 391 & 0.000 \\
\hline Employee satisfaction & 0.119 & 391 & 0.000 \\
\hline $\begin{array}{l}\text { Organizational } \\
\text { effectiveness }\end{array}$ & 0.106 & 391 & 0.000 \\
\hline $\begin{array}{l}\text { Financial results and the } \\
\text { market }\end{array}$ & 0.132 & 391 & 0.000 \\
\hline $\begin{array}{l}\text { Organizational } \\
\text { performance }\end{array}$ & 0.086 & 391 & 0.000 \\
\hline $\begin{array}{l}\text { Organizational } \\
\text { citizenship behavior }\end{array}$ & 0.049 & 391 & 0.027 \\
\hline
\end{tabular}

The normality of data was examined by the Kolmogorov-Smirnov test (k-s). As displayed in Table 2, normality assumption was not confirmed at the error level of 0.05 , because the probability value was lower than 0.05 .

First hypothesis (main hypothesis): there is a significant relationship between organizational citizenship behavior and organizational performance.

$H_{0}: \mathrm{r}=0$

$H_{1}: \mathrm{r} \neq 0$

Table 3. The relationship between organizational citizenship behavior and organizational performance

\begin{tabular}{|l|l|c|}
\hline \multirow{2}{*}{ Predictor variable } & \multicolumn{1}{|c|}{ Indicator } & Criterion variable \\
\cline { 3 - 3 } & & Organizational performance \\
\hline \multirow{3}{*}{$\begin{array}{l}\text { Organizational } \\
\text { citizenship } \\
\text { behavior }\end{array}$} & Correlation coefficient & 0.97 \\
\cline { 2 - 3 } & $\mathrm{R}^{2}$ & 0.94 \\
\cline { 2 - 3 } & Probability value & 0.000 \\
\cline { 2 - 3 } & Number of samples & 391 \\
\hline
\end{tabular}

As shown in Table 3, there is a significant relationship between organizational citizenship behavior and organizational performance. The correlation coefficient between organizational citizenship behavior and organizational performance is 0.97 and it has a positive direction. This correlation is significant at the error level of 0.05 , because the probability value was lower than 0.05 . According to the above table, $H_{0}$ is rejected and $H_{1}$ is confirmed. On the other hand, taking into account the coefficient of determination $\left(\mathrm{R}^{2}\right)$, it can be said that 0.94 of changes in organizational performance are related to organizational citizenship behavior. Thus, it is expected that market orientation increases by strengthening organizational citizenship behavior.

Second hypothesis: There is a significant relationship between organizational citizenship behavior and customer satisfaction.

$H_{0}: \mathrm{r}=0$

$H_{1}: \mathrm{r} \neq 0$

Table 4. The relationship between organizational citizenship behavior and customer satisfaction

\begin{tabular}{|l|l|c|}
\hline \multirow{2}{*}{ Predictor variable } & \multicolumn{1}{|c|}{ Indicator } & \multicolumn{1}{c|}{ Criterion variable } \\
\cline { 3 - 3 } & & Customer satisfaction \\
\hline \multirow{4}{*}{$\begin{array}{l}\text { Organizational } \\
\text { citizenship behavior }\end{array}$} & Correlation coefficient & 0.72 \\
\cline { 2 - 3 } & $\mathrm{R}^{2}$ & 0.51 \\
\cline { 2 - 3 } & Probability value & 0.000 \\
\cline { 2 - 3 } & Number of samples & 391 \\
\hline
\end{tabular}

As shown in Table 4, there is a significant relationship between organizational citizenship behavior and customer satisfaction. The correlation coefficient between organizational citizenship behavior and customer satisfaction is 0.72 and it has a positive direction. This correlation is significant at the error level of 0.05 , because the probability value was lower than 0.05 . According to the above table, $H_{0}$ is rejected and $H_{1}$ is confirmed. On the other hand, taking into account the coefficient of determination $\left(\mathrm{R}^{2}\right)$, it can be said that 0.51 of changes in customer satisfaction are related to organizational citizenship behavior. Thus, it is expected that customer satisfaction increases by strengthening organizational citizenship behavior.

Third hypothesis: there is a significant relationship between organizational citizenship behavior and employee satisfaction.

$H_{0}: \mathrm{r}=0$

$H_{1}: \mathrm{r} \neq 0$

Table 5 . The relationship between organizational citizenship behavior and employee satisfaction

\begin{tabular}{|l|l|c|}
\hline \multirow{2}{*}{ Predictor variable } & \multicolumn{1}{|c|}{ Indicator } & Criterion variable \\
\cline { 3 - 3 } & & Employee satisfaction \\
\hline \multirow{2}{*}{$\begin{array}{l}\text { Organizational } \\
\text { citizenship behavior }\end{array}$} & Correlation coefficient & 0.86 \\
\cline { 2 - 3 } & $\mathrm{R}^{2}$ & 0.73 \\
\hline
\end{tabular}


Table 5 (cont.). The relationship between organizational citizenship behavior and employee satisfaction

\begin{tabular}{|l|l|c|}
\hline \multirow{2}{*}{ Predictor variable } & \multicolumn{1}{|c|}{ Indicator } & Criterion variable \\
\cline { 3 - 3 } & & Employee satisfaction \\
\hline \multirow{2}{*}{$\begin{array}{l}\text { Organizational } \\
\text { citizenship behavior }\end{array}$} & Probability value & 0.000 \\
\cline { 2 - 3 } & Number of samples & 391 \\
\hline
\end{tabular}

As shown in Table 5, there is a significant relationship between organizational citizenship behavior and employee satisfaction. The correlation coefficient between organizational citizenship behavior and employee satisfaction is 0.86 and it has a positive direction. This correlation is significant at the error level of 0.05 , because the probability value was lower than 0.05 . According to the above table, $H_{0}$ is rejected and $H_{1}$ is confirmed. On the other hand, taking into account the coefficient of determination $\left(\mathrm{R}^{2}\right)$, it can be said that 0.73 of changes in employee satisfaction are related to organizational citizenship behavior. Thus, it is expected that employee satisfaction increases by strengthening organizational citizenship behavior.

Fourth hypothesis: There is a significant relationship between organizational citizenship behavior and organizational effectiveness.

$H_{0}: \mathrm{r}=0$

$H_{1}: \mathrm{r} \neq 0$

Table 6 . The relationship between organizational citizenship behavior and organizational effectiveness

\begin{tabular}{|c|l|c|}
\hline \multirow{2}{*}{ Predictor variable } & \multicolumn{1}{|c|}{ Indicator } & Criterion variable \\
\cline { 3 - 3 } & & Employee satisfaction \\
\hline \multirow{4}{*}{$\begin{array}{l}\text { Organizational } \\
\text { citizenship behavior }\end{array}$} & Correlation coefficient & 0.71 \\
\cline { 2 - 3 } & $\mathrm{R}^{2}$ & 0.50 \\
\cline { 2 - 3 } & Probability value & 0.000 \\
\cline { 2 - 3 } & Number of samples & 391 \\
\hline
\end{tabular}

As shown in Table 6, there is a significant relationship between organizational citizenship behavior and organizational effectiveness. The correlation coefficient between organizational citizenship behavior and organizational effectiveness is 0.71 and it has a positive direction. This correlation is significant at the error level of
0.05 , because the probability value was lower than 0.05 . According to the above table, $H_{0}$ is rejected and $H_{1}$ is confirmed. On the other hand, taking into account the coefficient of determination $\left(\mathrm{R}^{2}\right)$, it can be said that 0.50 of changes in organizational effectiveness are related to organizational citizenship behavior. Thus, it is expected that organizational effectiveness increases by strengthening organizational citizenship behavior.

There is a significant relationship between organizational citizenship behavior and financial results and the market.

$H_{0}: r=0$

$H_{1}: \mathrm{r} \neq 0$

Table 7. The relationship between organizational citizenship behavior and financial results and the market

\begin{tabular}{|l|l|c|}
\hline \multirow{2}{*}{ Predictor variable } & \multicolumn{1}{|c|}{ Indicator } & \multicolumn{1}{c|}{ Criterion variable } \\
\cline { 3 - 3 } & & Employee satisfaction \\
\hline \multirow{4}{*}{$\begin{array}{l}\text { Organizational } \\
\text { citizenship behavior }\end{array}$} & Correlation coefficient & 0.72 \\
\cline { 2 - 3 } & $\mathrm{R}^{2}$ & 0.51 \\
\cline { 2 - 3 } & Probability value & 0.000 \\
\cline { 2 - 3 } & Number of samples & 391 \\
\hline
\end{tabular}

As shown in Table 7, there is a significant relationship between organizational citizenship behavior and financial results and the market. The correlation coefficient between organizational citizenship behavior and financial results and the market is 0.72 and it has a positive direction. This correlation is significant at the error level of 0.05 , because the probability value was lower than 0.05 . According to the above table, $H_{0}$ is rejected and $H_{1}$ is confirmed. On the other hand, taking into account the coefficient of determination $\left(\mathrm{R}^{2}\right)$, it can be said that 0.51 of changes in financial results and the market are related to organizational citizenship behavior. Thus, it is expected that financial results and the market increases by strengthening organizational citizenship behavior.

Sixth hypothesis: There is a difference between organizational citizenship behavior and organizational performance in terms of gender.

$H_{0}: r=2$

$H_{1}: r \neq 2$

Table 8. Relationship between organizational citizenship behavior and organizational performance in terms of gender

\begin{tabular}{|c|c|c|c|c|c|}
\hline \multirow{2}{*}{ Group } & \multirow{2}{*}{ Predictor variable } & \multirow{2}{*}{ Indicator } & Criterion variable & \multirow{2}{*}{ Fisher z } & \multirow{2}{*}{ Probability value } \\
\hline & & & Organizational performance & & \\
\hline \multirow{3}{*}{ Women } & \multirow{3}{*}{ Organizational citizenship behavior } & Correlation coefficient & 0.96 & \multirow{3}{*}{7.083} & \multirow{3}{*}{0.000} \\
\hline & & Probability value & 0.000 & & \\
\hline & & Number of samples & 260 & & \\
\hline \multirow{3}{*}{ Men } & & Correlation coefficient & 0.99 & & \\
\hline & & Probability value & 0.000 & & \\
\hline & & Number of samples & 131 & & \\
\hline
\end{tabular}


As shown in Table 8, there is a significant relationship between organizational citizenship behavior and organizational performance among men and women. The correlation coefficient between organizational citizenship behavior and organizational performance is 0.96 and 0.99 among women and men, respectively, and it has a positive direction. This correlation for men is higher than women. According to the above table, $H_{0}$ is rejected and $H_{1}$ is confirmed.

\section{Conclusion}

The results of this research showed that there is a significant relationship between organizational citizenship behavior and organizational performance. The increasing trends of voluntary behavior or organizational citizenship behaviors by employees can positively increase organizational performance. Moreover, the increasing trends of voluntary behavior or organizational citizenship behaviors enhance the component of employee satisfaction more than other components of organizational performance. This indicates that OCB has a positive impact on customers and this trend is evident in increasing organizational performance. These results are consistent with the results of the studies conducted by Appelbaum (2004), Bienstock (2003), Bolino (2003), Castro (2004), Mehrdad (2005), Jalili (2010), Ekhlasi (2011), Bambale (2011), Tai et al. (2012), Magliocca \& Christakis (2001), Kark (2004). They concluded that OCB has a positive and significant impact on organizational performance.

Organizational citizenship behavior is an extra-role behavior through which employees improve the organizational performance and it is not directly or indirectly organized by the official reward system. For as much as increasing effectiveness has always been one of the issues and concerns of managers, organizational citizenship behavior and areas of deployment can be considered as an effective and helpful step in this way. Organizational citizenship behavior is a typical behavior for employees beyond what is officially described as arbitrary and is based on individual interests. Organizational citizenship behavior is a behavior that does not directly have a reward and is not appreciated through formal organizational structure. it is very important to organizational performance and success of organizations. Thus, it can be said that organizational citizenship behavior is very important to improve organizational performance.

\section{Suggestions}

- It is suggested that managers involve employees in setting goals and decisions of organizations and institutions to develop the organizational citizenship behavior, because the organizational citizenship behavior has a positive impact on some variables of organizations, especially organizational performance.

- Managers should give importance to employees' suggestions for improving procedures and organizational tasks. Managers should clearly define inter and intra functional roles.

- Managers must move toward the direction of development and enrichment of job and be involved in meaningful tasks and provide their employees with essential feedbacks.

- The establishment of suggestion system is essential for improving organizational citizenship behavior.

- Managers sometimes try to hold informal meetings for employees and managers and provide the employees with function and objectives of the organization.

- Employees and managers should have positive attitudes toward the organization which lead to promoting conscientiousness and loyalty within the organization.

- Managers and employees should try to create confidence in the workplace because confidence leads to the improvement and development of organizational citizenship behavior and, ultimately, results in performance improvement and organizational efficiency.

- Given that this study was conducted in a governmental organization, it is suggested that some researches are done in the private and semiprivate organizations and organizations and institutions outside the country and at the international level (such as commercial, military, medical, and engineering organization), so that their differences can be measured.

- This study focused on the relationship between organizational citizenship behavior and some dimensions of organizational performance. However, there are definitely other dimensions which researchers can consider them. Thus, it is suggested that researchers use some components such as commitment, culture, climate, environment, service, intelligence, skills, transformational leadership, and organizational structure as independent or moderator variables to investigate the relationship between organizational citizenship behavior and organizational performance.

\section{References}

1. Appelbaum, S., Bartolomucci, N., Beaumier, E., Boulanger, J., Corrigan, R., Dore, I., Girard, Ch. \&Serroni, C. (2004). Organizational citizenship behavior : a case study of culture, leadership and trust, Management decision, 42 (1), pp. 13-40. 
2. Alvani, S.M. (1999). Public administration. Tehran: Ney publications.

3. Ahmadi, M. (2013). Human resources management. $1^{\text {st }}$ edition. Sari: Cultural Researches.

4. Abo-jarard, I.Y., Yousof, N., Nikbin, D. (2010). A Review Paper on Organizational Culture and Organizational Performance, International Journal of Business and Social Science, 1 (3), pp. 26-46.

5. Bambale, A.J. (2011). Understanding Significant Relationships between Organizational Citizenship Behavior (OCB) and Marketing Function. Faculty of Commerce and Management Studies.

6. Bolino, M. and Turnley, W. (2003). Going the extra mile: cultivating and managing employee citizenship behavior, Academy of Management Executive, 17 (3), pp. 60-71.

7. Bienstock, C.C., Demoranville, W.C. \& Smith, K.R. (2003). Organizational citizenship behavior and service quality, Journal of services marketing, 17 (4), pp. 357-378.

8. Bass, B.M., Avolio, B.J. (1993). Transformational Leadership and Organizational Culture, Public Administration Quarterly, 17 (1), pp. 112-122.

9. Barney, J. (1991). Firm Resources and the Theory of Competitive Advantage, Journal of Management, 17, pp. 99-120.

10. Cohen, A. \& Kol, Y. (2004). Professionalism and organizational citizenship behavior. An empirical examination among Israeli nurses, Journal of managerial psychology, 19 (4).

11. Dess, G.G., Robinson, R.B. Jr. (1984). Measuring Organizational Performance in the Absence of Objective Measures, Strategic Management Journal, 5, pp. 265-273.

12. Dollery, B.E., Worthington, A.C. (1996). The Evaluation of Public Policy: Normative Economic Theories of Government Failure, Journal of Interdisciplinary Economics, 7, pp. 27-39.

13. Eslami, H. (2009). Organizational citizenship behavior. No. 187, Tadbir publications.

14. Cox, G. (2000). Customer Focus - a Commecial Imperative, Managing Service Quality, 7 (1). pp. 27-30.

15. George, J.M. and Brief, A.P. (1992). Feeling Good - doing Good: A Conceptual Analysis of the Mood at WorkOrganizational Spontaneity Relationship, Psychological Bulletin, 112, pp. 310-329.

16. Hadjali, H.R., Salimi, M. (2013). An Investigation on the Effect of Organizational Citizenship Behaviors (OCB) Toward Customer Orientation: A Case of Nursing Home, World Applied Sciences Journal, 28 (11), pp. 1710-1718.

17. Ho, L.A. (2008). What Affects Organizational Performance? Industrial Management \& Data Systems, 108 (9).

18. Hasangholipour, T., Ansari, M., Elahi Gol, A., Rahmani, H. (2012). Impact of internal marketing on market orientation through mediator variable of organizational commitment and organizational citizenship behavior in financial institutions (Case Study: Bank Mellat in Tehran city), Modern Marketing Journal, 2 (4), pp. 25-46.

19. Kark, R. (2004). The Transformational Leader, Who is (s)he? A Feminist Perspective, Journal of Organizational Change Management, 17 (2), pp. 160-176.

20. Kotler, P., Armstrong, G. (2001). Principles of Marketing. Translated by Ali Parsaeian, Jahan Nov Publications, Volume II.

21. Daft, L.R. (1999). Theoretical foundations and organizational design. Translated by: Ali Parsaeian and Mohammad Arabi, the Cultural Research Bureau publications.

22. Magliocca, L.A., Christakis, A.N (2001). Creating Transforming Leadership for Organizational Change: The Cogniscope System Approach, System Research and Behavioral Science, 18, pp. 259-277.

23. Mostabsary, M. \& Najaby, A.R. (2008). Job burnout as the moderating factor for OCB in the organization.

24. Neely, A.D., Adams, C., Kennerley, M. (2002). The Performance Prism: The Scorecard for Measuring and Managing Stakeholder Relationships. London: Financial Times/Prentice Hall.

25. Organ, D.W. (1988). Organizational Citizenship behavior: The good soldier syndrome. Lexington, MA: Lexington Books.

26. Podsakoff, P.M., Mackenzi, S.B., Paine, J.B. \& Bachrach, D.G. (2000). Organizatinal citizen ship behavior. A critical reviw of the theoretieal and empirical literature and suggestions for future research, Journal of management, 26 (3), pp. 513-536.

27. Rezaei Kelid Bari, H. \& Bagher Salimi, S. (2008). The role of organizational justice in strengthening organizational citizenship behavior.

28. Schappe, S.P. (1998). The Influence of Job Satisfaction, Organizational Commitment, and Fairness Perceptions on Organizational Citizenship Behavior, Journal of Psychology, 132 (3), pp. 277-287.

29. Tai, C.L., Chang, J., Che-Ming, L., Yu Hong, C.C. (2012). Alternative models for the relationship among leadership, organizational citizenship behavior, and performance: a study of new product development teams in Taiwan, Social and Behavioral Sciences, 57, pp. 511-517.

30. Vigoda, E. (2000). Internal politics in public administration Systems: an empirical examination of its relationship with Job congruence, organizational citizenship behaviour and in - role performance, Public Personnel Management, 29 (2), pp.185-203.

31. Winer, R.S. (2001). A Framework for Customer Relationship Management, California Management Review, 43, (4), pp. 89-100.

32. Zare, S. (2014). The effect of the position of internal marketing on the market orientation and organizational citizenship behavior (Case Study: branches of Saderat Bank in the city of Yazd). International Conference on Accounting, economic and financial management Journal. 